\title{
international news
}

\section{Fast-breeder urged}

by Allan Piper

THE UK standing Royal Commission on Environmental Pollution, which has had the radiological safety aspects of Britain's nuclear programme under consideration since the beginning of last year, has conceded that there is a case for establishing a full-scale demonstration power station based on the controversial fast-breeder reactor (FBR). In an open letter to the Prime Minister, the commission's chairman, Sir Brian Flowers, acknowledged the importance of the FBR in Britain's energy strategy and admitted that "there are arguments for pressing ahead [with a demonstration FBR] on a reasonable time scale. To do so is to be better prepared".

Sir Brian's letter was apparently prompted by fears that the British government would reach an early decision to proceed with a commercial-scale reactor in collaboration with other European governments before the commission's investigation was complete. A demonstration FBR, "remotely sited [with] its own fuel reprocessing and fabrication plant", is seen as vital for assessing the hazards of operating a commercial fast reactor. The letter does make the point, however, that the UK need not allow itself to become finally committed to the FBR at the expense of research into other energy sources. It notes that the commission is not "yet persuaded that the energy needs of the UK in the next 30-50 years are such as unavoidably to require the deployment of FBRs on a massive scale."

Were it not for the apparent paradox of an environmental watchdog body calling for the construction of a controversial type of reactor, the publication of Sir Brian's text might have been the non-event of the year. Not only is the primary recommendation of the letter couched in predictably reserved terms, it is also little more than a reiteration of what is effectively the policy of the United Kingdom Atomic Energy Authority (UKAEA).

For some time it has been widely accepted that the next logical step in the UKAEA's development programme for fast reactors would be the construction of a demonstration reactor on a commercial scale. The prototype 250 MW reactor at Dounreay seems just about to have survived its bout of teething problems, but the UKAEA's tentative plans for the construction of a 1,300 MW demonstration installation nonetheless involve time-scales that seem surprisingly short. The authority has talked of having a demonstration fast-breeder by the early 1980 s, though the Department of Energy's decision will depend on prospects for European collaboration.

It is not altogether clear why the text of the letter should have appeared at this particular time, especially as the Prime Minister denied in his reply that an early decision on the FBR programme was expected. Sir Brian and the Prime Minister shared a platform on the day after the publication of the letter, the key passage of which highlighted "the distinction between the environmental implications of a fullscale demonstration FBR station and of a large ongoing nuclear programme". What that means is that the construction of a UKAEA demonstration reactor, which would be only nominally commercial, might be taken to signal a total commitment to the FBR, whereas the construction of the same reactor in line with the commission's recommendation can be viewed as part of an environmental appraisal.

\section{Protest over Sakharov}

\section{from Vera Rich, London}

ThE award of the 1975 Nobel Peace Prize to Academician Andrei Sakharov has inevitably drawn considerable attention to the whole problem of human rights and academic freedom in the Soviet Union. Sakharov was refused a visa to travel to Oslo to collect his prize, and a group of former Nobel winners has now issued a statement on behalf of the refusnik scientists "deprived of the freedom to work, to publish, to teach, and to travel freely, simply because they have sought to emigrate from the USSR".

They note that "we shall never regard scientific exchanges with the USSR as being easy and normal while these people are deprived of their rights... while arbitrary and needless bars to freedom and work are enforced and while bargains are entered into and unilaterally set aside, the existence of detente will remain pre- carious". The "bargain" referred to is the one which the Soviet authorities made last year with Academician Veniamin Levich, whom they promised would have permission to emigrate at the end of 1975 when his security restriction expired. In October they denied that any such promise had been made.

Signatories to the statement include Professor Sir Derek Barton, Professor Sir Hans Krebs, Professor Rodney Porter, Professor Sir George Porter and Professor Max Perutz.

Meanwhile, Dr Leonid Kantorovich, joint winner of this year's Nobel Prize for Economics, arrived in Stockholm to receive his prize with the necessary exit visas and approvals demanded by the Soviet authorities. He declined to comment on their refusal to allow Academician Sakharov to travel to Oslo.

\section{Soviet grain estimate cropped}

from Vera Rich, London

DurING this year, the estimates for the Soviet grain harvest have been consistently revised downwards from the planned yield of 215.7 million tonnes announced last spring. The final figure has, however, proved to be even lower than expected. In a statement made to the Supreme Soviet on December 3, Grigorii Vashchenko, Chairman of the Planning and Budgetary Commission, said that the average annual grain production for the ninth five-year plan (which ends this year) had exceeded that of the previous plan by $8 \%$.

Comparative figures are a classical gambit of Soviet planners who wish to put the best possible political face on a deficit. Translated in real terms, however, Vashchenko's 8\% "increase" corresponds to a total production of some 137 million tonnes, more than a quarter of the planned output. This figure, which received wide publicity in the Western media, was promptly denied by the foreign service of Moscow Radio. Moscow Radio claimed that the figures had been manipulated and that, properly understood, they reflected a "steady planned progress". In a similar way, the industrial growth rate of $4.3 \%$ for the coming year-the lowest since the Second World War, almost certainly as a result of the disastrous 